\title{
STABILISASI TANAH LEMPUNG SEBAGAI SUBGRADE \\ DENGAN MEMANFAATKAN KAPUR PADAM ASAL KABUPATEN PANGKEP
}

\author{
Ermitha Ambun Rombe Dendo \\ ambunrombe@gmail.com
}

\section{INTISARI}

Tanah lempung merupakan tanah yang sangat mudah mengalami kembang susut akibat perubahan kadar air dan memiliki daya dukung yang lemah. Jenis tanah ini dapat berada di beberapa tempat yang mengalami kerusakan. Beberapa cara dapat dilakukan untuk mengatasinya adalah dengan melakukan stabilisasi kimiawi dengan memanfaatkan kapur ataupun semen. Penelitian ini digunakan kapur padam yang berasal dari Kabupaten Pangkep Propinsi Sulawesi Selatan.

Penelitian dilakukan dengan mengadakan pencampuran tanah lempung yang berasal dari ruas jalan di Desa Bungoro Kabupaten Pangkep Propinsi Sulawesi dengan menggunakan kapur padam dengan variasi prosentase 3\%, 6\%, 9\% dan 12\%. Kemudian dilakukan pengujian batas-batas Atterberg, kepadatan, sweeling CBR dan uji CBR Soaked.

Hasil penelitian menunjukkan bahwa penggunaan kapur padam dapat menaikkan nilai CBR. Pemberian kapur pada dengan variasi sebanyak 3\%, 6\%, 9\% dan $12 \%$ menaikkan nilai CBR tanah berturut-turut menjadi $17,14 \% ; 23,59 \% ; 27,80 \%$ dan $29,84 \%$. Selain itu pemberian kapur padam pada tanah lempung juga dapat menaikkan nilai kuat tekan bebas setelah dilakukan pemeraman. Untuk pemeraman selama 3 hari dengan prosentase kapur padam $3 \%$ hingga $12 \%$ menaikkan nilai kuat tekan bebas dari $4,38 \mathrm{~kg} / \mathrm{cm}^{2}$ untuk kadar kapur $3 \%$ naik hingga $8,52 \mathrm{~kg} / \mathrm{cm}^{2}$ untuk kadar kapur padam $12 \%$. Sedangkan untuk pemeraman selama 6 hari dengan variasi penambahan kapur padam 3\% hingga 12\% juga menaikkan menaikkan nilai kuat tekan bebas dari $5,59 \mathrm{~kg} / \mathrm{cm}^{2}$ untuk kadar kapur $3 \%$ naik hingga $12,77 \mathrm{~kg} / \mathrm{cm}^{2}$ untuk kadar kapur padam $12 \%$.

Pemanfaatan kapur pada dengan prosentase 3\% sampai $12 \%$ dapat membantu perbaikan sifat-sifat fisis dan meningkatkan nilai kuta dukung tanah.

Kata kunci : Stabilisasi, tanah lempung ekspansif, kapur padam. 


\section{PENDAHULUAN}

Tanah merupakan aspek penting dalam pekerjaan konstruksi teknik sipil sebab hampIr seluruh konstruksi teknik sipil meletakkan struktur pekerjaan diatas tanah. Dalam perancangan konstruksi jalan raya tanah dasar (subgrade) merupakan bagian yang penting karena tanah dasar akan mendukung seluruh kontruksi lapis keras badan jalan beserta dengan beban lalu lintas yang akan lewat diatasnya. Menurut Hardiyatmo (2006), tanah berasal dari pelapukan batuan yang menjadi butiran yang terjadi secara fissi maupun kimia dengan atau ytanpa kandungan organik. Sifat fisis tanah dipengaruhi oleh sifat batuan induk yang merupakan material asalnya.

Tanah dasar yang baik dan dapat digunakan untuk konstruksi perkerasan jalan adalah tanah yang bersal dari lokasi itu sendiri ataupun dari daerah didekatnya dan telah dipadatkan sampai pada tingkat kepadatan tertentu, sehingga mempunyai daya dukung yang baik serta berkemampuan mempertahankan perubahan volume selama masa pelayanan walaupun terdapat perbedaan kondisi lingkungan dari tanah tersebut.

Tanah dasar adalah bagian terpenting dari konstruksi jalan sebab berfungsi untuk mendukung beban lapis perkerasan dan beban lalu lintas diatasnya. Saat ini sering ditemukan jaringan jalan harus melalui daerah yang tanah aslinya secara geoteknis tidak menguntungkan, artinya tanah tersebut tidak memenuhi syarat untuk dapat digunakan sebagai bahan tanah dasar (subgrade), misalnya tanah lempung ekspansif yang memiliki nilai CBR atau daya dukung yang rendah, pengembangan (sweeling) yang besar dan plastisitas yang tinggi. Hal tersebut dapat menyebabkan tidak stabilnya lapis perkerasan jalan sehingga permukaan jalan dapat menjadi rusak seperti terjadinya retak - retak pada permukaan jalan, bergelombang ataupun amblas. Salah satu cara untuk mengatasi hal tersebut adalah perbaikan tanah dengan melakukan stabilisasi dari tanah lempung tersebut dengan menambahkan kapur padam.

Kapur padam (hydrated lime) atau $\mathrm{Ca}(\mathrm{OH})_{2}$ merupakan hasil pembakaran dari batu alam dan dilakukan pemadaman dengan penambahan air. Kapur yang digunakan pada penelitian ini berasal gunung kapur di Kabupaten Pangkep, yang akan dikaji kemungkinan pemanfaatannya sebagai bahan stabisator untuk tanah lempung eksapansif.

\section{PERUMUSAN MASALAH}

Tanah lempung merupakan tanah berbutir halus yang mempunyai sifat sangat peka terhadap perubahan kadar air sehingga mudah terjadi perubahan volume. Hal ini akan menurunkan kuat dukungnya sehingga tidak memungkinkan untuk dapat digunakan sebagai tanah dasar (subgrade). Oleh sebab itu perlu dilakukan perbaikan sifat 
tanah lempung tersebut yang kemudian disebut sebagai stabilisasi. Salah satu cara stabilisasi yang dapat dilakukan adalah dengan mencoba menambah dan mencampurkan kapur padam pada tanah lempung yang akan digunakan sebagai tanah dasar.

\section{TUJUAN PENELITIAN}

Tujuan dari penelitian adalah untuk mengkaji mengetahui seberapa jauh pengaruh dan perubahan sifat atau karakteristik tanah lempung ekspansif dengan adanya penambahan dan pencampuran kapur padam dengan kadar yang bervariasi.

\section{METODE PENELITIAN}

Penelitian dilakukan dengan uji laboratorium dengan menggunakan sampel kapur padam dari Kabupaten Pangkep Propinsi Sulawesi Selatan dan sampel tanah yang diambil dari Desa Bungoro Kabupaten Pangkep Propinsi Sulawesi Selatan.

A. Pengujian yang dilakukan meliputi :

1. Pengujian tanah asli meliputi :
a. Pengujian kadar air (water content)
b. Pengujian berat jenis tanah (specific gravity)
c. Pengujian batas cair (liquid limit)
d. Pengujian batas plastis (plastic limit)
e. Analisa butiran
f. Pengujian kepadatan standar
g. Pengujian indeks pengembangan
h. Pengujian CBR Soaked
i. Pengujian kuat tekan bebas

2. Pegujian campuran tanah dengan kapur padam. Setelah tanah dicampurkan dengan kapur padam, dilakukan pengujian meliputi :

a. Pengujian batas-batas Atterberg.

b. Pengujian pemadatan.

c. Pengujian CBR Soaked

d. Pengujian swelling potensial

e. Pengujian kuat tekan bebas

\section{B. Metode Pencampuran}

Pencampuran bahan-bahan dilakukan dalam keadaan kering udara, dengan variasi pencampuran kapur padam yang digunakan adalah $3 \%, 6 \%, 9 \%$ dan $12 \%$ dari berat kering tanah hingga homogen kemudian ditambahkan air sesuai kadar air optimum yang telah didapatkan pada percobaan pemadatan sebelumnya pada masing masing campuran.

\section{Pengujian pelengkap}

Pada pengujian pelengkap yang dilakukan sebagai data pendukung pada penelitian meliputi kandungan mineral pada tanah lempung dengan fraksi sinar X, kandungan $\mathrm{Al}$ dan Si serta $\mathrm{Ca}$ dan Mg. 


\section{ANGGAPAN DASAR DAN HIPOTESA}

Pada penelitian ini, kapur yang digunakan adalah kapur padam (hydrated lime) yang rumus kimianya $\left(\mathrm{Ca}(\mathrm{OH})_{2}\right)$ dengan kandungan kalsiumnya sebesar $49 \%$ dengan prosentase 3\%, $6 \%, 9 \%$ dan $12 \%$, dapat menaikkan nilai CBR dan modulus elastistanah lempung ekspansif.

Menurut Transport Research Board Commite on Lime (1987), cara untuk mengetahui besarnya perubahan yang terjadi dengan lamanya pemeraman. Lamanya pemeraman dapat menurunkan nilai plastisitas tanah bahkan dapat merubah keadaan menjadi non plastis serta kekuatan tanah akan meningkat seiring semakin lamanya waktu yang diberikan untuk pemeraman.

\section{HASIL PENELITIAN DAN PEMBAHASAN}

\section{Klasifikasi Tanah}

Pengklasifikasian jenis tanah menggunakan sistem klasifikasi American Association of State Highway and Transportation Official (AASHTO) dan Unified Soil Classification System (USCS).

Pengujian distribusi partikel dilakukan dengan saringan dan analisa hydrometer. Hasil pengujian ditampilkan pada Tabel 1 .

Tabel 1. Distribusi Ukuran Partikel Tanah Lempung

\begin{tabular}{|c|c|}
\hline No. Saringan & $\begin{array}{c}\text { Prosentase lewat } \\
(\%)\end{array}$ \\
\hline 10 & 100 \\
\hline 12 & 100 \\
\hline
\end{tabular}

\begin{tabular}{|c|c|}
\hline 40 & 97,80 \\
\hline 100 & 97,20 \\
\hline 200 & 96,60 \\
\hline
\end{tabular}

\section{a. Klasifikasi Sistem AASHTO}

Berdasarkan hasil pemeriksaan distribusi butiran pada sampel tanah, diperoleh hasil bahwa fraksi tanah yang lolos saringan no. 200 adalah 96,6\% dan termasuk jenis lanau atau lempung pada klasifikasi kelompok A-4 sampai A-7 karena prosentase lolos lebih besar dari 35\%. Untuk fraksi yang lolos saringan no. 40, persyaratan batas cair minimum $41 \%$ dan indeks plastisitas minimum 11\%. Dari hasil pemeriksaan tanah diperoleh nilai batas cair $75 \%$ dan indeks plastisitas $45,05 \%$ sehingga tanah termasuk golongan A-7-6(29).

\section{b. Klasifikasi Sistem Unified}

Menurut sistem unified, jika fraksi tanah yang lolos saringan no. 200 lebih dari 50\%, maka tanah termasuk jenis berbutir halus (lanau atau lempung) dan jika nilai batas cair lebih dari 50\% maka termasuk dalam $\mathrm{CH}$ atau $\mathrm{MH}$. Dari data yang diperoleh dari hasil pengujian, bila diplotkan kedalam diagrag plastisitas dengan nilai batas cair $75 \%$ dan indeks plastisitasnya 45,05\%, maka menurut sistem unified sampel tanah adalah $\mathrm{CH}$ atau lempung tak organic dengan plastisitas tinggi atau lempung gemuk (fat clay). 


\section{Tanah lempung}

Hasil pengujian karakteristik tanah lempung disajikan pada Tabel 2 berikut ini :

Tabel 2. Karakteristik Tanah Lempung

\begin{tabular}{|c|l|c|}
\hline No. & \multicolumn{1}{|c|}{ Pemeriksaan } & Nilai \\
\hline 1. & Kadar air kering udara $(w)$ & $8,24 \%$ \\
\hline 2. & Berat Jenis (Gs) & $2,675 \%$ \\
\hline 3. & Batas Cair (LL) & $75,00 \%$ \\
\hline 4. & Batas Plastis (PL) & $29,95 \%$ \\
\hline 5. & Indeks Plastisitas (PI) & $46,05 \%$ \\
\hline 6. & Berat Volume kering Maksimum & $1,385 \mathrm{gr} / \mathrm{cm}^{3}$ \\
\hline 7. & Kadar air optimum & $27,33 \%$ \\
\hline 8. & Sweeling Potensial & $28,82 \%$ \\
\hline 9. & Sweeling CBR & $3,6 \%$ \\
\hline 10. & CBR Soaked & $2,52 \%$ \\
\hline 11. & Kuat Tekan Bebas & $1,86 \mathrm{~kg} / \mathrm{cm}^{2}$ \\
\hline 12. & Modulus Elastisitas & $102,23 \mathrm{~kg} / \mathrm{cm}^{2}$ \\
\hline
\end{tabular}

\section{Kapur Padam}

Jenis kapur padam yang digunakan memiliki kandungan kalsium dan magnesium dapat dilihat pada Tabel 3 berikut ini :

Tabel 3. Karakteristik Kapur Padam

\begin{tabular}{|c|c|c|}
\hline No. & Pemeriksaan & Nilai \\
\hline 1. & Kandungan Ca & $49,93 \%$ \\
\hline 2. & Kandungan $\mathrm{Mg}$ & $2,1 \%$ \\
\hline
\end{tabular}

\section{Campuran Tanah dan Kapur Padam}

\section{a. Pengaruh Penambahan Kapur Padam Terhadap Nilai Batas-Batas Atterberg.}

Tanah lempung dicampur dengan kapur padam kemudian dilakukan pengujian batas-batas
Atterberg. Penambahan kapur padam sebanyak $3 \%$ menyebabkan terjadinya penurunan batas cair sebesar $10,7 \%$ yaitu dari $75,00 \%$ menjadi $67 \%$ dan terus menurun seiring bartambahnya kadar kapur hingga menjadi 65\%. Hal ini disebabkan oleh menurunnya fraksi lempung dalam campuran, sehingga daya serap air oleh butiran tanah dalam campuran menjadi berkurang.

Indeks plastisitas merupakan rentang keplastisan suatu tanah yaitu antara batas cair dan batas plastis. Dari hasil pengujian terlihat bahwa dengan penambahan kapur padam kedalam tanah lempung dapat mengurangi indeks plastisitas tanah. Hal ini disebabkan oleh berkurangnya sifat daya lekat tanah lempung dalam campuran.

Hasil pengujian batas-batas Atterberg pada campuran tanah dan kapur padam dapat dilihat pada Tabel 4.

Tabel 4. Hasil Pengujian Batas-Batas Atterberg Campuran Tanah dengan Kapur Padam

\begin{tabular}{|c|c|c|c|c|}
\hline No. & $\begin{array}{c}\text { Kadar } \\
\text { Kapur } \\
(\%)\end{array}$ & $\begin{array}{c}\text { Batas } \\
\text { Cair } \\
(\%)\end{array}$ & $\begin{array}{c}\text { Batas } \\
\text { Plastis } \\
(\%)\end{array}$ & $\begin{array}{c}\text { Indeks } \\
\text { Plastis } \\
(\%)\end{array}$ \\
\hline 1 & 3 & 67 & 40.94 & 26,06 \\
\hline 2 & 6 & 66,29 & 43.68 & 22,61 \\
\hline 3 & 9 & 67,55 & 48.55 & 18,95 \\
\hline 4 & 12 & 65,00 & 49.01 & 15,99 \\
\hline
\end{tabular}

Pengujian batas-batas atterberg juga dilakukan terhadap campuran tanah lempung dan kapur padam yang telah diperam selama 3 hari dan 6 hari. Dengan pemeraman diharapkan dapat 
memberikan waktu cukup pada tanah untuk dapat bereaksi dengan kapur. Dari hasil yang diperoleh, terlihat bahwa pemeraman selama 3 hari terjadi reduksi plastisitas yang sangat menonjol untuk penambahan kapur padam sebanyak 3\%, 6\%, 9\% dan $12 \%$, dimana nilai plastisitas menurun dari $45,05 \%$ menjadi $13,47 \%$ dan $11,15 \%$ untuk penambahan kapur sebanyak $3 \%$ dan $6 \%$. Sedangkan untuk penambahan kapur padam sebanyak $9 \%$ dan $12 \%$, keadaan tanah menjadi non plastis. Hal ini disebabkan adanya aksi pozolanik (pozzolanik action) yang sangat kuat antara komponen utama tanah yaitu alumina dan silika dengan kapur. Reaksi ini dapat terjadi dalam jangka waktu panjang tergantung dari waktu yang diberikan untuk bereaksi yaitu waktu pemeraman. Hasil pengujian batas-batas Atterberg pada campuran tanah dan kapur padam yang telah diperam selama 3 hari dapat dilihat pada Tabel 5.

Tabel 5. Hasil Pengujian Batas-Batas Atterberg Campuran Tanah dengan Kapur Padam Untuk Pemeraman 3 Hari

\begin{tabular}{|c|c|c|c|c|}
\hline No. & $\begin{array}{c}\text { Kadar } \\
\text { Kapur } \\
(\%)\end{array}$ & $\begin{array}{c}\text { Batas } \\
\text { Cair } \\
(\%)\end{array}$ & $\begin{array}{c}\text { Batas } \\
\text { Plastis } \\
(\%)\end{array}$ & $\begin{array}{c}\text { Indeks } \\
\text { Plastis } \\
(\%)\end{array}$ \\
\hline 1 & 3 & 52,5 & 39,03 & 13,47 \\
\hline 2 & 6 & 48 & 36,85 & 11,15 \\
\hline 3 & 9 & 43 & NP & NP \\
\hline 4 & 12 & 44 & NP & NP \\
\hline
\end{tabular}

\section{b. Pengaruh Penambahan Kapur Padam Terhadap Potensi Pengembangan Tanah Lempung}

Tanah lempung adalah tanah yang sangat mudah mengalami kembang susut akibat pengaruh air yang dikandungnya. Pengembangan akan bertambah dengan naiknya kadar air dan akan jenuh air jika telah mencapai mancamai maksimal.

Uji potensi pengembangan campuran tanah lempung dan kapur padam dilakukan dengan uji weeling potensisl dengan waktu perendaman selama 4 hari dengan maksud agar tanah telah mencapai kondisi jenuh untuk mewakili kondisi terburuk di lapangan, sehingga pengembangan tanah menjadi maksimal. Dari hasil uji sweeling potensial pada campuran tanah lempung dan kapur padam ternyata dapat menurunkan nilai pengembangan seiring bertambahnya prosentase kadar kapur dalam campuran. Tanah asli memiliki potensi pengembangan sebesar 28,22\%, setelah diberikan dicampurkan dengan kapur padam, terjadi reduksi pengembangan sebesar 19,32\% untuk kadar kapur 3\% dan terus turun hingga kadar kapur $12 \%$ dengan nilai reduksi sebesar 57,8\%. Hasil uji sweeling potensial tanah setelah dicampur dengan kapur padam dapat dilihat pada Tabel 6. 
Tabel 6. Hasil Pengujian Sweeling Potensial Campuran Tanah dan Kapur Padam

\begin{tabular}{|c|c|}
\hline No. & Nilai Sweeling (\%) \\
\hline 1. & 22,76 \\
\hline 2. & 19,76 \\
\hline 3. & 11,88 \\
\hline
\end{tabular}

Penambahan kapur padam yang mempunyai gradasi yang lebih kasar dari tanh lempung akan mengurangi fraksi lempung dalam campuran. Hal ini akan mengurangi sifat plastis dan sifat kohesif dari tanah lempung. Dengan demikian hal ini juga akan mengurangi derajat aktifitas dan potensi pengembangan tanah. Selain itu kapur padam juga mempunyai sifat menyerap air dalam campuran, maka dengan peningkatan jumlah kapur padam dalam campuran akan menguirangi air yang akan menyelimuti partikel lempung sehingga struktur campuran akan menjadi lebih rapat saat pemadatan. Dengan demikian hal ini akan mengurangi potensi pengembangan.

\section{c. Pengaruh Penambahan Kapur Padam Terhadap Nilai CBR Soaked}

Faktor yang mempengaruhi nilai CBR adalah jenis dan kualitas bahan, tingkat kepadatan dan kerapatan butiran. Kualitas bahan sangat berhubungan erat dengan kekerasan/kekuatan, kohesi dan susut gesek internal dari butiran. Bahan yang keras artinya bila menerima bebabn tidak akan mudah hancur dan tidak mudah mengalami perubahan bentuk. Selain itu ikatan antar butir sangat diperlukan, sehingga semakin kuat ikatan akan menghasilkan nilai CBR yang tinggi. Penambahan kapur padam sebesar 3\% menaikkan nilai CBR dari 2,84\% menjadi $17,14 \%$ dan naik terus seiring dengan penambahan kadar kapur dalam campuran menjadi $12 \%$ dengan nilai CBR menjadi 29,84\%. Hasil pengujian CBR dilakukan dengan pengujian CBR Soaked pada campuran tanah dengan kapur padam dapat dilihat pada Tabel 7.

Tabel 7. Hasil Pengujian CBR Soaked Pada Campuran Tanah dan Kapur Padam

\begin{tabular}{|c|c|c|}
\hline No & $\begin{array}{c}\text { Kadar Kapur } \\
(\%)\end{array}$ & Nilai CBR (\%) \\
\hline 1. & 3 & 17,14 \\
\hline 2. & 6 & 23,59 \\
\hline 3. & 9 & 27,80 \\
\hline 4. & 12 & 29,84 \\
\hline
\end{tabular}

Dari hasil pengujian dapat diketahui bahwa dengan adanya penambahan kapur padam pada tanah lempung menyebabkan naiknya nilai CBR. Hal ini disebabkan gradasi dalam campuran mengalami perubahan dimana gradasi kapur padam yang lebih kasar akan mengurangi fraksi butir halus tanah lempung dalam campuran sehingga mengurangi indeks plastisitas dan meningkatkan kekuatan, kepadatan dan kekerasan campuran. 


\section{d. . Pengaruh Penambahan Kapur Padam Terhadap Nilai Kuat Tekan Bebas Pada Campuran}

Prosedur perancangan campuran yang digunakan untuk menentukan nilai kuat tekan bebas dari campuran tanah lempung adan kapur padam adalah prosedur AASTHO T-220.

Hasil pengujian kuat tekan bebas pada campuran tanah dengan kapur padam dengan pemeraman dan tanpa pemeraman dapat dilihat pada Tabel 8 sampai pada Tabel 10.

Tabel 8. Hasil Pengujian Kuat Tekan Bebas dan Modulus Elastisitas Pada Campuran Tanah dan Kapur Padam Tanpa Pemeraman

\begin{tabular}{|c|c|c|c|}
\hline No & $\begin{array}{c}\text { Kadar } \\
\text { Kapur } \\
(\%)\end{array}$ & $\begin{array}{c}\text { Kuat Tekan } \\
\text { Bebas } \\
\left(\mathrm{kg} / \mathrm{cm}^{2}\right)\end{array}$ & $\begin{array}{c}\text { Modulus } \\
\text { Elastisitas } \\
\left(\mathrm{kg} / \mathrm{cm}^{2}\right)\end{array}$ \\
\hline 1. & 3 & 3,26 & 232,86 \\
\hline 2. & 6 & 2,83 & 202,14 \\
\hline 3. & 9 & 2,33 & 194,17 \\
\hline 4. & 12 & 1,38 & 75 \\
\hline
\end{tabular}

Tabel 9. Hasil Pengujian Kuat Tekan Bebas dan Modulus Elastisitas Pada Campuran Tanah dan Kapur Padam Pemeraman 3 Hari

\begin{tabular}{|c|c|c|c|}
\hline $\begin{array}{c}\mathrm{N} \\
\mathrm{o}\end{array}$ & $\begin{array}{c}\text { Kadar } \\
\text { Kapur } \\
(\%)\end{array}$ & $\begin{array}{c}\text { Kuat } \\
\text { Tekan } \\
\text { Bebas } \\
\left(\mathrm{kg} / \mathrm{cm}^{2}\right)\end{array}$ & $\begin{array}{c}\text { Modulus } \\
\text { Elastisitas } \\
\left(\mathrm{kg} / \mathrm{cm}^{2}\right)\end{array}$ \\
\hline 1. & 3 & 4,38 & 277,21 \\
\hline 2. & 6 & 4,80 & 303,79 \\
\hline 3. & 9 & 8,04 & 909,10 \\
\hline 4. & 12 & 8,52 & 990,69 \\
\hline
\end{tabular}

Tabel 10. Hasil Pengujian Kuat Tekan Bebas dan Modulus Elastisitas Pada Campuran Tanah dan Kapur Padam Pemeraman 6 Hari

\begin{tabular}{|c|c|c|c|}
\hline No & $\begin{array}{c}\text { Kadar } \\
\text { Kapur } \\
(\%)\end{array}$ & $\begin{array}{c}\text { Kuat Tekan } \\
\text { Bebas } \\
\left(\mathrm{kg} / \mathrm{cm}^{2}\right)\end{array}$ & $\begin{array}{c}\text { Modulus } \\
\text { Elastisitas } \\
\left(\mathrm{kg} / \mathrm{cm}^{2}\right)\end{array}$ \\
\hline 1. & 3 & 5,59 & 310,55 \\
\hline 2. & 6 & 8,60 & 330,76 \\
\hline 3. & 9 & 10,41 & 945,45 \\
\hline 4. & 12 & 12,77 & $1.277,00$ \\
\hline
\end{tabular}

\section{d.1. Tanpa pemeraman}

Hasil uji tekan bebas (qu) dan modulus elastisitas pada tanah asli memberikan nilai masing-masing sebesar $1,86 \mathrm{~kg} / \mathrm{cm}^{2}$ dan 102,22 $\mathrm{kg} / \mathrm{cm}^{2}$. Setelah ditambahkan kapur padam sebanyak 3\% terjadi kenaikan nilai kuat tekan bebas menjadi $3,26 \mathrm{~kg} / \mathrm{cm}^{2}$ dan $232,86 \mathrm{~kg} / \mathrm{cm}^{2}$ untuk nilai modulus elastisitasnya. Namun pada penambahan kadar kapur padam 6\%, 9\% dan 12\%, nilai terjadi penurunan nilai kuat tekan bebas dan modulus elastisitas menjadi $2,83 \mathrm{~kg} / \mathrm{cm}^{2}$ dan $202,14 \mathrm{~kg} / \mathrm{cm}^{2}$ dan terus turun menjadi $1,38 \mathrm{~kg} / \mathrm{cm}^{2}$ dan $75 \mathrm{~kg} / \mathrm{cm}^{2}$ untuk kadar kapur dalam campuran sebesar 12\%, seperti terlihat pada Tabel no. 8. Hal ini terjadi karena campuran antara tanah dan kapur padam belum terjadi reaksi yang baik.

\section{d.2 Pemeraman 3 hari}

Dengan pemeraman selama 3 hari, dimana tanah dan kapur diberi waktu untuk bereaksi sehingga terjadi pertukaran kation, flukulasi dan agglomerasi, maka pada penambahan kapur padam 
sebanyak 3\%, 6\%, 9\% dan $12 \%$ dapat menaikkan nilai kuat tekan bebas masing - masing menjadi $4,38 \mathrm{~kg} / \mathrm{cm}^{2}, \quad 4,80 \mathrm{~kg} / \mathrm{cm}^{2}, \quad 8,04 \mathrm{~kg} / \mathrm{cm}^{2}$ dan $8,52 \mathrm{~kg} / \mathrm{cm}^{2}$ untuk nilai kuat tekan. Sedangkan untuk nilai modulus elastisitas tanah naik menjadi $277,21 \mathrm{~kg} / \mathrm{cm}^{2}$ untuk kadar kapur 3\%; 305,17 $\mathrm{kg} / \mathrm{cm}^{2}$ untuk kadar kapur 6\%; 909,10 kg/ $\mathrm{cm}^{2}$ untuk kadar kapur 9\% dan 990,69 kg/cm² untuk kadar kapur $12 \%$. Hal ini terjadi karena campuran antara tanah dan kapur padam mulai terjadi reaksi yang baik.

\section{d.3 Pemeraman 6 hari}

Pada peraman selaman 6 hari untuk campuran tanah lempung dan kapur padam sebanyak 3\%, menaikkan nilai kuat tekan bebas menjadi $5,59 \mathrm{~kg} / \mathrm{cm} 2$ dan modulus elastis menjadi $310,55 \mathrm{~kg} / \mathrm{cm} 2$. Untuk campuran dengan kadar kapur padam 6\%, 9\% dan 12\% nilai kuat tekan bebas juga terus bertambah masing-masing menjadi $8,60 \mathrm{~kg} / \mathrm{cm} 2,10,41 \mathrm{~kg} / \mathrm{cm} 2$, dan 12,77 $\mathrm{kg} / \mathrm{cm} 2$, sedangkan untuk modulus elastisitas tanah lempung menjadi masing-masing $330,76 \mathrm{~kg} / \mathrm{cm} 2$, 945,45 kg/cm2 dan $1277 \mathrm{~kg} / \mathrm{cm} 2$. Dengan kenaikan nilai-nilai tersebut berarti bahwa dengan semakin lama waktu pemeraman yang diberikan pada campuran tanah dan kapur padam maka kekuatan tanah juga bertambah, sebab campuran antara tanah dan kapur padam telah bereaksi dengan baik.

\section{KESIMPULAN}

\section{Kesimpulan}

1. Penambahan kapur padam pada tanah lempung dapat menurunkan kadar air dan menaikkan kepadatan campuran, disebabkan gradasi campuran lebih kasar dan fraksi halus dari tanh lempung dalam campuran berkurang sehingga jumlah air yang akan menyelimuti butiran menjadi berkurang.

2. Penggunaan kapur padaham dengan $3 \%$ sampai $12 \%$ dapat menurunkan indeks plastisitas tanah, sehingga potensi pengembangan tanah, sehingga aktivitas tanah menjadi lebih berkurang.

3. Pengaruh pemeran selama 3 hari dan 6 hari pada campuran tanah lempung dan kapur padam menunjukkan perubahan sifat fisis yang lebih baik dibandingkan tanpa pemeraman.

4. Dari hasil pengujian terhadap campuran tanah lempung dan kapur padam dapat menaikkan nilai CBR tanah dari 2,84\% menjadi $17,14 \%$.

\section{SARAN}

\section{Saran}

1. Dari hasil pengujian laboratorium, membuktikan bahwa bahan kapur padam dapat digunakan sebagai bahan campuran untuk peningkatan sifat-sifat fisis dan daya dukung tanah lempung sebagai tanah dasar (subgrade), terutama untuk menangani 
masalah jaringan jalan yang kondisi tanah aslinya adalah tanah lempung.

2. Perlu dilakukan penelitian dengan pengujian lainnya seperti uji kekuatan tarik, uji permeabilitas dan uji konsolidasi.

3. Perlu dilakukan penelitian untuk pencampuran kapur padam dengan bahan lainnya yang dianggap adapt digunakan dengan pertimbangan nilai ekonomis.

\section{DAFTAR PUSTAKA}

Bowles, 1984, Sifat-Sifat Fisis Tanah dan Geoteknis tanah, Penerbit Erlangga, Jakarta, Indonesia

Das, 1985, Mekanika Tanah, (Prinsip-Prinsip Rekayasa Geologi) Jilid I, Penerbit Erlangga, Jakarta, Indonesia

Direktorat Jenderal Bina Marga Jakarta, 1976, Manual Pemeriksaan Bahan Jalan, Direktorat Jenderal Bina Marga, Jakarta

Hadiyatmo, 2006, Penanganan Tanah Longsor dan Erosi, Gajah Mada University Press, Yogyakarta, Indonesia
Ingles, O.G and Metcalf, J.B, 1972, Soil Stabilitazion Principles and Practice, Butterworths Pty. Limited, Australia

Mitchell JK, 1993, Fundamental of Soil Behavior, John Willey and Son, New York, USA

Soekoto, I, 1984, Memepersiapkan Lapis Dasar Konstruksi, Badan Penerbit PU, Jakarta, Indonesia

Terzaghi dan B. Peck, 1987, Mekanika Tanah dalam Praktek Rekayasa, Penerbit Erlangga, Jakarta, Indonesia

Transportation Research Board, 1987, Lime Stabilization, National Research Council, Washington DC, USA 